DOI 10.18551/rjoas.2019-03.11

\title{
THE ROLE OF FARMERS IN EFFORTS TO INCREASE THE EMPOWERMENT OF DAIRY CATTLE FARMERS GROUP: A CASE STUDY AT NGANTRU VILLAGE OF EAST JAVA PROVINCE, INDONESIA
}

\author{
Sarjono Wasis* \\ Doctoral Program, Faculty of Agriculture, University of Brawijaya, Malang, Indonesia \\ Yuliati Yayuk, Sugiyanto, Sukesi Keppi \\ Faculty of Agriculture, University of Brawijaya, Malang, Indonesia \\ *E-mail: sarjonowasis@gmail.com
}

\begin{abstract}
Empowerment is the process of, by and for the community, where people are accompanied or facilitated in making decisions and taking their own initiative so that they are more independent in developing and improving their living standard. This study uses a qualitative approach that aims to determine the characteristics role of farmers in an effort to improve the empowerment of groups of dairy farmers. The snowball sampling technique is a method for identifying, selecting and taking samples in a network or a continuous chain of relationships. The research uses three research approaches, namely, observation, in-depth interviews, literature studies (document analysis) as a triangulation process. The research findings show that farmers who have cattle $<5$ tails still use conventional farming systems. The number of cattle ownership plays an important role in the group empowerment process. This is related to the existing social inequalities. Generally farmers who have a small number of cattle have different perceptions of thinking in the process of adopting the innovation and in community relations. Farmers who join the groups' are the farmers with an education level of elementary school graduates and the majority of men who already married. This happens because the role of men after becoming head of the family is to control all activities that are outside the home, while women control activities that are inside the house. Character differences related to age, length of cattle raising, number of cattle, gender, and education level lead to differences in the mindset that will influence the decision-making process and adoption of technological innovations.
\end{abstract}

\section{KEY WORDS}

Empowerment, characteristics, farmer groups, qualitative approaches.

In an effort to support the fulfillment of the needs of fresh milk products on an ongoing basis conducted the improvement of the zootechnics application quality in the dairy farming business. The zootechnics enhancement activities include the selection of superior seeds, providing comfortable cages for cattle, providing good feed, handling the health, handling the reproduction, handling the production and handling the birth properly. Achievement of the above conditions requires improvement and development effort in Human Resources (HR), so that they have good knowledge, attitude and skills. Dairy cattle business is one of the livestock business that has strategic value, because the dairy products produced are needed by the community, besides that dairy cattle business can help the community, especially in terms of family economy, industrial raw material suppliers, providing employment and can help maintain the environment by utilizing organic fertilizers (Mukson, et al., 2009).

The low level of quality and productivity of cattle is caused more by a lack of capital, as well as knowledge or skills of farmers covering aspects of production, feeding, management of post-harvest results, application of recording systems, milking, sanitation and disease prevention (Nisa et al., 2012; Phillips, 2018; Muraya et al., 2018; Laurence et al., 2018; Agus \& widi, 2018; Manning et al., 2018; Asai et al., 2018; and Pham \& Waibel; 2018). Efforts to increase knowledge, attitudes, and skills are directed to foster the dynamics of institutional 
organization of farmer groups, so that dairy farmers are able to experience an empowerment process that includes a desire to change in improving business activities, awareness to eliminate and release less productive habits that cause waste, the level of sense of belonging to the business and the institutional functions of the group is increasing, able to develop self-capacity and increase responsibility, spur the ability to achieve higher production in business, always improve self-competence so that it impacts on behavior change in a more efficient and effective business, and ready to face challenges to advance its business.

In the empowerment framework, the farmer organization system is needed for the development strategy of farmer organizations consisting of several sub-systems, namely: (1) rules for playing in institutions (rules of the game) involving all members; (2) the growth of member participants; (3) counseling and assistance in the application of technology; (4) increase the commitment of each manager and member to the goals set; and (5) developing a good environment (natural, social and economic). The group of dairy farmers in an area can be seen as a system of farmers' economic organization. Zakaria (2009) states that empowerment strategies in terms of farmers' economic development consist of: (1) organizational or institutional empowerment; (2) development of a network of business partnerships; and (3) competitiveness improvement, where all three must be carried out gradually, consistently and sustainable in accordance with the economic performance of the target farmers.

The development of dairy cattle is certainly inseparable from the role of groups of farmers in seeking their livestock to get added value and efficient management. Efforts that need to be developed in fostering and strengthening farmer groups are to strengthen the economic institutions of farmers in rural areas. Through a group of dairy farmers it is hoped that farmers can interact with each other, so that they have the impact of mutual need, enhance each other, strengthen each other, so that it will increase knowledge and ability in managing the dairy farming business system (Apriyanto, et al, 2017).

Most of the farmers in Ngantang Subdistrict are community farms that have a population of cattle between 2-25 cows. The number of farmers recorded by KUD Sumber Makmur currently 3100 farmers that produce 85 tons of milk per day. Most of the farmers, have run their businesses for 16-25 years. While the majority of farmers are in the age range of 31 to 70 years. Farmers whose the age are over 50 tend to be passive and walk in the same direction as young group members. Some studies suggest that age and work experience affect productivity (Almutahar et al., 2016). The last education of the majority of farmers in Ngantang Subdistrict was elementary school graduates, there were even some farmers who did not graduate from elementary school, only a few graduated from junior high school and high school graduated. Mulyawati, et al. (2016) stated that the education level of farmers can influence farmers in adaptation and innovation in raising livestock., Soekartawi (1988) in Waris, et al. (2015) states that those with higher education are relatively quicker to understand the adoption of innovation, and vice versa, those with low education are difficult to implement adoption of innovation quickly.

The dairy farming business in Ngantang Sub-district is carried out where among other business actors are interdependent on meeting the production and marketing facilities of the dairy products produced. Most of the milk produced by community farms are distributed to the cooperatives/KUD persusuan which are then marketed to the Dairy Processing Industry. Cooperatives provide services to farmers as members, in the form of marketing their products also serving the needs of concentrates, medicines, Artificial Insemination services, provide credit distribution facilities, and provide counseling services. In addition, institutionally among farmers, cooperatives and IPS must carry out their partnership patterns in a synergistic manner. The synergy of dairy cooperatives in the national dairy farming area must be supported by a targeted strategy. According to Kasim et al. (2011) in Priyono and Priyanti (2015), a strategy that can be done to develop dairy cattle among others by increasing population, empowering the business loans, optimizing the land, applying technology, business partnerships and improving the cultivation management. 
Empowerment of farmer groups is inseparable from the characteristics of farmers (age, gender, education, number of livestock (tails) and breeding time) which is one of the determinants of success in the business of dairy cattle. From the above explanation, it is necessary to examine how the role of the characteristics of farmers in an effort to increase the empowerment of a group of dairy farmers in Ngantru Village, Ngantang Sub-District, Malang Regency. East Java.

\section{METHODS OF RESEARCH}

This study uses a qualitative approach. This approach makes it possible for researchers to choose the main strategy, namely, case studies, as revealed by Yin (2003) in Yona (2006) case study as a method in conducting a study of phenomena that occur with a focus on one's life experience (real life context). The selection of a case study strategy is based more on the characteristics and habits of the dairy farmer community at the research site, which is hereditary and continuously takes place in the community in Malang Regency. The strategy of this case study is expected to open the opportunity for dialogue among researchers, informants and subjects as well as the occurrence of interactions among and within the researchers, informants and subjects. This study refers to the constructivist paradigm (Cresswell, 1994) in Hajaroh (2010), in the sense that researchers will construct a model of empowerment of dairy farmers based on group dynamics and innovation in environmentally friendly dairy farming in the research location. So the results of this study, is a construction that is defined jointly between the researchers with the studied subject. The informant is determined by snowball technique. According to Nurdiani (2014), the snowball sampling technique is a method for identifying, selecting and taking samples in a network or continuous chain of relationships. The researcher presents a network through sociogram images in the form of images of circles that are linked or connected by lines. Each circle represents one respondent or case and lines show the relationship between respondents or between cases. Or the method in which the sample is obtained through the process of rolling from one respondent to another, usually this method is used to explain social or communication (sociometric) patterns of a particular community.

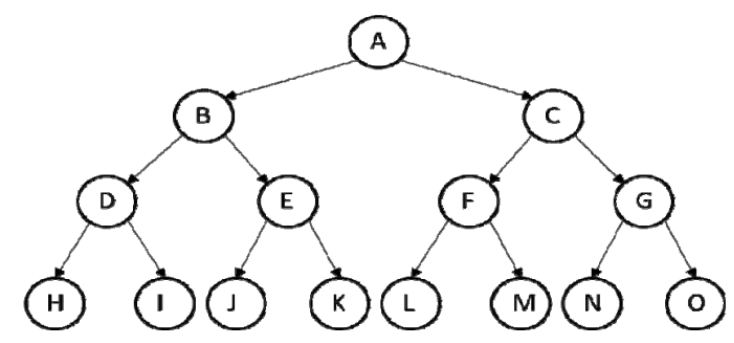

Figure 1 - Snowball Sampling technical chart (Nurdiani, 2014)

This study will use three research approaches, namely, observation, in-depth interviews, literature studies (document analysis) as a triangulation process. Qualitative data analysis according to Miles and Huberman (1992: 15-21) in Vantikasari (2017) explains that there are three lines of qualitative data analysis, namely data reduction, data presentation, and conclusion drawing.

\section{RESULTS AND DISCUSSION}

The informants in this study were the core administrators and three members of the farmer groups assisted by the KUD Sumber Makmur and the Gemah Ripah IV independent farmer group in Ngantru Village, Ngantang SubDistrict, Malang Regency. The characteristics of the informants in the study consisted of age, gender, last education, ownership of the number of livestock/cattle and experience in raising livestock/cattle. 
Table 1 - Informant Characteristics

\begin{tabular}{lllll}
\hline No & Informant Characteristic & Criteria & Total & Percentage \\
\hline 1. & Age & Young (16-30) & 0 & 0 \\
& & Adult (31-45) & 6 & 50 \\
& & Advanced adult (46-70) & 6 & 50 \\
2. & Gender & Male & 12 & 100 \\
& & Female & 0 & 0 \\
3. & Last Education & Not completed in primary school & 1 & 8,3 \\
& & Primary school & 5 & 41,7 \\
& & Junior high school & 3 & 25 \\
& & High school & 3 & 25 \\
4. Number of cattle (tails) & College & Small (1-5) & 0 & 0 \\
& & Medium (5-15) & 1 & 8,3 \\
& & High (>15) & 6 & 50 \\
5. & Length of cattle raising & New (1-5) & 5 & 41,7 \\
& & Medium (16-25) & 0 & 0 \\
& & Old (26-40) & 12 & 100 \\
\hline
\end{tabular}

Age is a benchmark in the ease of receiving information, wether included in the productive and non-productive age groups and how much is the burden on the family (Puspitasari and Umrotun, 2016). The results of the research in Table 1 show that the age of respondents ranged from 16 to 70 years. Ages $31-45$ years old are six people or $50 \%$. Ages 46-70 years old are six people or $50 \%$. Farmers who join the farmer group are mostly 31-70 years old. In this age range farmers have a high level of loyalty to the group. This is because farmers are more comfortable and pursue activities carried out by farmer groups. Utami (2015) states that age affects the ability to work. In accordance with Poluan, et al (2017), which states that the age level makes a person's ability to carry out activities either physically and the concept of different thinking. Young members become their own capital for the group because they have stronger physical conditions, broad insight, a desire to try new things, have creative thinking skills and the ability to access information through higher technology. Conversely, someone who is old or elderly tends to be passive. Supported by Sujaya, et al. (2018) which states that the increasing age of farmers will reduce the physical abilities and thinking of farmers that have an impact on decreasing the productivity achieved in the dairy farming business.

Male respondents amounted to 12 people or $100 \%$. Farmers who are members of farmer groups are mostly men who already married. This happens because the role of men after becoming head of the family is to control all activities that are outside the home, while women control activities that are inside the house. Farmer group is an organization that is run out of the house, so people prefer a man who played an active role in it. This causes the majority who join the farmer groups are the men that an active role in it (Ojango et al., 208; Wardrop et al., 2018; Wijers, 2019; Rubin et al., 2019; Wilson, 2018, and Mead, 2018). This is what causes the majority who join the farmer group to be male. The results of this study are in accordance with Hubeis (2010), which states that the division of labor according to gender refers to the way in which all types of work (reproductive, productive and social) are divided between men and women, and how the work is valued and appreciated in a society or certain cultures. In the household, there is a clear division of tasks between family members. Men are generally dominant in public and community work, while women are dominant in reproductive work (domestic activities: preparing food, collecting water, looking for firewood, shopping, maintaining family health and nutrition, caring for and educating children).

The role of men in farmer groups, has not been able to optimize the group empowerment process. In groups besides the men's thinking, women's thinking is also needed, so that there is no gap in opinion. In addition, when women are involved in groups, it is expected that group problems will be resolved, especially those related to women. So that it will have a positive impact on the group empowerment process. Hasanah and Musyafak (2018), stated that gender equality involves men and women in addressing issues related to 
development, reforming institutions to build equal rights and opportunities, and encouraging economic development that strengthens equality of participation. This kind of approach aims to improve the gaps that continue to exist regarding access to natural resources and the ability to express opinions.

The majority of the last education of the respondents was elementary/primary school graduates, namely as many as five people or $41,6 \%$, did not graduate from elementary/primary school equal to one person or $8,3 \%$, graduated from junior high school and high school respectively three people or $25 \%$. Farmers who join the farmer group are mostly elementary/ primary school graduates. According to Poluan, et al (2017), the higher the education level of a person, the more knowledge or insight that is possessed, whether it is creating, applying new technologies as well as new innovations. In addition, the higher the level of education, the more mature someone is in acting. Thus, educational factors have a negative impact on the group empowerment process, because groups will find it more difficult to provide education and change the mindset of members.

Murwanto (2015) added that the level of farmer education is an indicator of population quality and is a key variable in human resource development. Adequate farmers' education can facilitate the process of receiving livestock innovation and technology. According to Yusdja and Ilham (2006) in Hastang (2014), low-educated human resources (HR) will hamper livestock business development, and according to Yasin and Dilega (1993) in Hastang (2014) that high-educated and knowledgeable farmers are fast and precise in accepting and implementing new innovations. Thus farmers who are highly educated have greater opportunities to increase income. This is in accordance with the results of Misriani's research (2011) that the level of education is positively correlated with farmer income. This condition is certainly an important note considering the aspirations that the members of the group want to filter out certainly have relevance to the level of formal education that members of the group have. This is in line with Ibrahim's (2001) opinion that the higher the level of education, caused the individual insight gets better and the more diverse sources of information they use so that the types of messages received is also increasing.

Farmers in Ngantang Subdistrict who join the farmer group have the majority of livestock businesses on a household scale, where the number of dairy cows owned ranges from 1-25. Types of farmers in Ngantang Subdistrict according to KUD Sumber Makmur are classified into three, namely: small farmers with a population of 1-5 tails, medium with a population of 6-15 tails, and large with a population of $>15$ tails. From the information obtained during the interview, the veterinarian from the KUD institution said that farmers who have $<5$ tails of cattle still use conventional farming systems. The number of cattle ownership plays an important role in the group empowerment process. This is related to existing social inequalities. Generally farmers who have a small number of cattle have different perceptions of thinking in the process of adopting innovation and in community relations.

Soekartawi (1988) in Lestari, et al (2009); Senyolo et al. (2018); Tutusaus et al. (2018); Jayashankar et al. (2018); Ntshangase et al. (2018); Massaro \& de Theije (2018); Lima et al. (2018); Arvila et al. (2018); Soto et al. (2018); and Alomia-Hinojosa et al. (2018) states that many new technologies require large scale operations and high economic resources for the need for innovation adoption, so that the scale of farming scale is always positively associated with innovation adoption. Conversely the use of better technology will produce economic benefits that can also expand the further farming business.

Farmers who join the group have been in business for 16-25 years. Farmers who have been running livestock business for a long time will be easier to implement technology than beginner farmers. This is because more experience makes farmers can make comparisons in making decisions. Role in making decisions that have been experienced will have a positive impact on the process of empowering groups. Djamali (2000); Rougoor et al (1998); Musvoto et al. (2018), and Mankiw \& Nortje (2014) states that adequate education and experience will open horizons of understanding the technical principles and economic principles that become the requirement for the success of a farming manager. However, the long experience of farming can also make farmers more careful in making decisions, as stated by Soehardjo and Patong (1973), in Hastang (2014) that farmers who have more 
experience will always be careful in acting with the existence of bad experience in the past. With the long experience of farming that has been undertaken, then it is expected that the farmer has been skilled in the technical business of his livestock, so that farmers can think rationally and make the right decisions in developing their livestock through farmer groups. Popkin (1986); Rose et al. (2018); Šūmane et al. (2018); Xu et al. (2016); Higgins et al. (2018); Rigg et al. (2018); Guéneau (2018); Garforth (2015); Donati (2019); and Mayer (2018) argues that the activities of farmers in running their livestock business make farmers think rationally about the conditions in the world of animal husbandry/ farming. Farmers are independent individuals in implementing decisions that are considered most appropriate and in accordance with their expectations. The experience of cattle raising causes a sense of responsibility for everything that is done in making all decisions.

The characteristics of the following farmers play an important role in the process of empowering farmers. Differences in character related to age, length of cattle raising, number of cattle, gender, and level of education lead to differences in the mindset that will influence the decision making process and adoption of technological innovations.

\section{CONCLUSION AND RECOMMENDATIONS}

Based on the findings of this study concluded that the number of livestock/cattle ownership plays an important role in the group empowerment process. This is related to the existing social inequalities. Generally farmers who have a small number of cattle have different perceptions of thinking in the process of adopting innovation and in community relations. It can be seen that character differences related to age, length of cattle raising, number of cattle, gender, and level of education cause differences in the mindset that will affect the decision making process and adoption of technological innovation. Old-aged and low-educated farmers tend to be followers and are slow to adopt innovation. This research recommends the importance of the role of government extension/counseling agents more indicated through regular monthly meetings/yasinan for both independent groups and KUD to disseminate government activities and other information regarding dairy farming.

\section{REFERENCES}

1. Agus, A., \& Widi, T. S. M. 2018. Current situation and future prospects for beef cattle production in Indonesia - A review. Asian-Australasian journal of animal sciences, 31(7), 976.

2. Almutahar, F. F. 2016. Pengaruh Usia, Pengalaman Kerja, Disiplin Kerja and Motivasi Kerja terhadap Produktivitas Pekerja pada Pekerjaan Pemasangan Dinding Batako. Jurnal Mahasiswa Teknik Sipil Universitas Tanjungpura, 1(1).

3. Alomia-Hinojosa, V., Speelman, E. N., Thapa, A., Wei, H. E., McDonald, A. J., Tittonell, P., \& Groot, J. C. 2018. Exploring farmer perceptions of agricultural innovations for maize-legume intensification in the mid-hills region of Nepal. International journal of agricultural sustainability, 16(1), 74-93.

4. Apriyanto, A. L., Irdaf, I., and Kusumastuti, A. E. 2017. Peranan kelompok peternak sapi potong Satwa Mulya terhadap keberdayaan rumah tangga peternak di Desa Brajan, Kecamatan Mojosongo, Kabupaten Boyolali Jawa Tengah. Jurnal IImu-Ilmu Peternakan, 26(3), 79-90.

5. Arvila, N., Fischer, A., Keskinen, P., \& Nieminen, M. 2018. Mobile weather services for Maasai farmers: socio-cultural factors influencing the adoption of technology. In Proceedings of the Second African Conference for Human Computer Interaction: Thriving Communities (p. 4). ACM.

6. Asai, M., Moraine, M., Ryschawy, J., de Wit, J., Hoshide, A. K., \& Martin, G. 2018. Critical factors for crop-livestock integration beyond the farm level: A cross-analysis of worldwide case studies. Land use policy, 73, 184-194.

7. Donati, K. 2019. 'Herding is his favourite thing in the world': Convivial world-making on a multispecies farm. Journal of Rural Studies. 
8. Garforth, C. 2015. Livestock keepers' reasons for doing and not doing things which governments, vets and scientists would like them to do. Zoonoses and public health, 62, 29-38.

9. Guéneau, S. 2018. Neoliberalism and the emergence of private sustainability initiatives: the case of the Brazilian cattle value chain. Business Strategy and the Environment, $27(2), 240-251$.

10. Hajaroh, M. 2010. Paradigma, Pendekatan and Metode Penelitian Fenomenologi. Jurnal Pendidikan Universitas Negeri Yogyakarta, 1-21.

11. Hasanah, U., and Musyafak, N. 2018. Gender And Politics: Keterlibatan Perempuan dalam Pembangunan Politik. Sawwa: Jurnal Studi Gender, 12(3), 409-432.

12. Hastang, A. A. 2014. Analisis Keuntungan Peternak Sapi Potong Berbasis Peternakan Rakyat Di Kabupaten Bone. Jiip, 1(3), 240-252

13. Higgins, V., Bryant, M., Hernández-Jover, M., Rast, L., \& McShane, C. 2018. Devolved Responsibility and On-Farm Biosecurity: Practices of Biosecure Farming Care in Livestock Production. Sociologia ruralis, 58(1), 20-39.

14. Hubeis, A. V. S. 2010. Pemberdayaan perempuan dari masa ke masa. IPB Press.

15. Ibrahim JT. 2001. Kajian reorientasi penyuluhan pertanian ke arah pemenuhan kebutuhan petani di Provinsi Jawa Timur. [Disertasi]. Bogor (ID): Institut Pertanian Bogor.

16. Jayashankar, P., Nilakanta, S., Johnston, W. J., Gill, P., \& Burres, R. 2018. IoT adoption in agriculture: the role of trust, perceived value and risk. Journal of Business \& Industrial Marketing, 33(6), 804-821.

17. Laurence, M., Accioly, J. M., Copping, K. J., Deland, M. P. B., Graham, J. F., Hebart, M. L., ... \& Pitchford, W. S. 2018. Divergent genotypes for fatness or residual feed intake in Angus cattle. 2. Body composition but not reproduction was affected in first-parity cows on both low and high levels of nutrition. Animal Production Science, 58(1), 43-54.

18. Lestari, W., Hadi, S., and Idris, N. 2009. Tingkat adopsi inovasi peternak dalam beternak ayam broiler di Kecamatan Bajubang Kabupaten Batang Hari. Jurnal IImiah IImu-IImu Peternakan, 14-22.

19. Lima, E., Hopkins, T., Gurney, E., Shortall, O., Lovatt, F., Davies, P., Kaler, J. 2018. Drivers for precision livestock technology adoption: A study of factors associated with adoption of electronic identification technology by commercial sheep farmers in England and Wales. PloS one, 13(1), e0190489.

20. Mankiw, N. G. 2014. Principles of economics. Cengage Learning.

21. Manning, J. K., Cronin, G. M., Bishop, T. F. A., González, L. A., Merchant, A., \& Ingram, L. J. 2018. The effect of pasture quality on herd site selection of beef cattle. Heterogeneity in extensive pasture systems: the effect on beef cattle behaviour, selection, paddock utilisation and production, 122.

22. Massaro, L., \& de Theije, M. 2018. Understanding small-scale gold mining practices: An anthropological study on technological innovation in the Vale do Rio Peixoto (Mato Grosso, Brazil). Journal of Cleaner Production, 204, 618-635.

23. Mayer, E. 2018. The articulated peasant: household economies in the Andes. Routledge.

24. Mead, M. 2018. Cooperation and competition among primitive peoples. Routledge.

25. Misriani, V. 2011. Hubungan Karakteristik Peternak and Jumlah Ternak yang Dipelihara dengan Pendapatan pada Pembibitan Sapi Potong Rakyat di Kecamatan Bayang Kabupaten Pesisir Selatan. Skripsi. Fakultas Peternakan Universitas Andalas. Padang.

26. Mukson, M., Ekowati, T., Handayani, M., and Harjanti, D. W. 2009. Faktor-faktor yang mempengaruhi kinerja usaha ternak sapi perah rakyat di Kecamatan Getasan Kabupaten Semarang. In Prosiding Seminar Nasional Kebangkitan Peternakan-Semarang, 20 Mei 2009 (pp. 339-345). Fakultas Peternakan UNDIP Semarang.

27. Mulyawati, I. M., Mardiningsih, D., and Satmoko, S. 2016. Pengaruh Umur, Pendidikan, Pengalaman and Jumlah Ternak Peternak Kambing terhadap Perilaku Sapta Usaha Beternak Kambing di Desa Wonosari Kecamatan Patebon. Agromedia, 34(1).

28. Muraya, J., VanLeeuwen, J. A., Gitau, G. K., Wichtel, J. J., Makau, D. N., Crane, M. B., Tsuma, V. T. 2018. Cross-sectional study of productive and reproductive traits of dairy 
cattle in smallholder farms in Meru, Kenya. Livestock Research for Rural Development, 30.

29. Murwanto, A. G. 2015. Karakteristik Peternak and Tingkat Masukan Teknologi Peternakan Sapi Potong di Lembah Prafi Kabupaten ManokwariKarakteristik Peternak and Tingkat Masukan Teknologi Peternakan Sapi Potong di Lembah Prafi Kabupaten Manokwari. Journal of Tropical Animal and Veterinary Science, 3(1).

30. Musvoto, C., \& Nortje, K. 2018. The Socio-Economic Context of Green Economy Implementation in the Agriculture Sector. In Green Economy Implementation in the Agriculture Sector (pp. 13-39). Springer, Cham.

31. Nisa, H. I., Santoso, S. I., and Mukson, M. 2012. Analisis Profitabilitas USAha Ternak Sapi Perah Anggota Kud di Kabupaten Semarang. Animal Agriculture Journal, 1(1), 319337.

32. Ntshangase, N., Muroyiwa, B., \& Sibanda, M. 2018. Farmers' perceptions and factors influencing the adoption of no-till conservation agriculture by small-scale farmers in Zashuke, KwaZulu-Natal Province. Sustainability, 10(2), 555.

33. Nurdiani, N. 2014. Teknik sampling snowball dalam penelitian lapangan. ComTech: Computer, Mathematics and Engineering Applications, 5(2), 1110-1118.

34. Ojango, J. M., Oyieng, E. P., Milla, D., Audho, J., Kariuki, J. B., and Jakinda, S. (2018). Best practices for selective breeding for improved livestock productivity: Feed the Future Kenya Accelerated Value Chain Development Program Module 2-Engage.

35. Pham, H. D., \& Waibel, H. 2018. Risk attitudes, knowledge, skills and agricultural productivity (No. WP-007). TVSEP Working Paper.

36. Phillips, C. J. 2018. Principles of cattle production. CABI.

37. Poluan, Rantung, V. V., and Ngangi, C. R. 2017. Dinamika Kelompok Tani Maesaan Waya di Desa Manembo, Kecamatan Langowan Selatan. AGRI-SOSIOEKONOMI, 13(1A), 217-224.

38. Popkin SL. 1986. Petani Rasional. Jakarta (ID): Lembaga Penerbit Yayasan Padamu Negeri.

39. Priyono, and Priyanti. 2015. Penguatan kelembagaan koperasi susu melalui pendekatan pengembangan kawasan peternakan nasional. Wartazoa, 25(2), 85-94.

40. Rigg, J., Salamanca, A., Phongsiri, M., \& Sripun, M. 2018. More farmers, less farming? Understanding the truncated agrarian transition in Thailand. World Development, 107, 327-337.

41. Rose, D. C., Morris, C., Lobley, M., Winter, M., Sutherland, W. J., \& Dicks, L. V. 2018. Exploring the spatialities of technological and user re-scripting: The case of decision support tools in UK agriculture. Geoforum, 89, 11-18.

42. Rougoor, C. W., Trip, G., Huirne, R. B., \& Renkema, J. A. 1998. How to define and study farmers' management capacity: theory and use in agricultural economics. Agricultural economics, 18(3), 261-272.

43. Rubin, D., Ferdousi, S., Parvin, A., Rahaman, S. M., Rahman, S., Rahman, W., \& Redoy, M. (2018). Qualitative research on women's empowerment and participation in agricultural value chains in Bangladesh. Intl Food Policy Res Inst.

44. Senyolo, M. P., Long, T. B., Blok, V., \& Omta, O. 2018. How the characteristics of innovations impact their adoption: An exploration of climate-smart agricultural innovations in South Africa. Journal of cleaner production, 172, 3825-3840.

45. Soto, I., Barnes, A., Eory, V., Beck, B., Balafoutis, A., Sanchez, B., Gomez-Barbero, M. 2018. Which factors and incentives influence the intention to adopt precision agricultural technologies?

46. Sujaya, D. H., Hardiyanto, T., and Isyanto, A. Y. 2018. Faktor-Faktor Yang Berpengaruh Terhadap Produktivitas Usahatani Mina Padi Di Kota Tasikmalaya. Mimbar Agribisnis: Jurnal Pemikiran Masyarakat Ilmiah Berwawasan Agribisnis, 4(1), 25-39.

47. Šūmane, S., Kunda, I., Knickel, K., Strauss, A., Tisenkopfs, T., des los Rios, I., Ashkenazy, A. 2018. Local and farmers' knowledge matters! How integrating informal and formal knowledge enhances sustainable and resilient agriculture. Journal of Rural Studies, 59, 232-241. 
48. Tutusaus, M., Schwartz, K., \& Smit, S. 2018. The ambiguity of innovation drivers: The adoption of information and communication technologies by public water utilities. Journal of cleaner production, 171, S79-S85.

49. Utami, A. W. 2015. Analisis Produktivitas Tenaga Kerja Pada Usaha Domba. Students eJournal, 4(3).

50. Vantikasari, N. 2017. Pemberdayaan Masyarakat Nelayan Oleh Kelompok Nelayan Tuna Jaya Di Desa Tasikmasdu Kecamatan Watulimo Kabupaten Trenggalek. IAIN Tulungagung.

51. Wardrop, N. A., Hill, A. G., Dzodzomenyo, M., Aryeetey, G., and Wright, J. A. (2018). Livestock ownership and microbial contamination of drinking-water: Evidence from nationally representative household surveys in Ghana, Nepal and Bangladesh. International journal of hygiene and environmental health, 221(1), 33-40.

52. Waris, N. B., and Wahyuning, D. A. 2015. Pengaruh tingkat pendidikan, usia, and lama beternak terhadap pengetahuan manajemen reproduksi ternak sapi potong di desa Kedungpring Kecamatan Balongpanggang Kabupaten Gresik. Jurnal Ternak, 6(01), 3033.

53. Wijers, G. D. 2019. Inequality regimes in Indonesian dairy cooperatives: understanding institutional barriers to gender equality. Agriculture and Human Values, 1-15.

54. Wilson, F. M. 2018. Organizational behaviour and work: a critical introduction. Oxford university press.

55. Xu, X., Li, X., Qi, G., Tang, L., \& Mukwereza, L. 2016. Science, technology, and the politics of knowledge: The case of China's agricultural technology demonstration centers in Africa. World Development, 81, 82-91.

56. Yona, S. 2006. Penyusunan Studi Kasus. Jurnal Keperawatan Indonesia, 10(2), 76-80. 